\title{
Ardra Profiles Of Bacteria And Archaea In Mangrove Sediments With Different Levels Of Contamination In The Estuarine Complex Of Paranaguá, Brazil
}

\author{
Catherine Gérikas Ribeiro" ${ }^{1}$, Maria Berenice Reynaud Steffens ${ }^{2}$, Rafael Mazer Etto ${ }^{3}$, \\ Carolina Weigert Galvão ${ }^{3}$, César de Castro Martins ${ }^{4}$, Fábio de Oliveira Pedrosa ${ }^{2}$ and \\ Hedda Elisabeth Kolm ${ }^{4 *}$ \\ ${ }^{1}$ Laboratório de Biogeoquímica Marinha; Instituto Oceanográfico; Universidade de São Paulo; Praça do \\ Oceanográfico, 191; 05508-120; São Paulo - SP - Brasil . .'Departamento de Bioquímica e Biologia Molecular; \\ Universidade Federal do Paraná; Curitiba - PR - Brasil. ${ }^{3}$ Laboratório de Biologia Molecular Microbiana; \\ Universidade Estadual de Ponta Grossa; Ponta Grossa - PR - Brasil. ${ }^{4}$ Centro de Estudos do Mar; Universidade \\ Federal do Paraná; Pontal do Paraná - PR - Brasil
}

\begin{abstract}
The mangrove's sediments from the coastal areas under human activities may contain significant contaminations by hydrocarbons, even when there are no visual evidences of it. The microorganisms are essential to these ecosystems, especially in the control of their chemical environment. Sediment samples were collected in two regions under different environment conditions (pristine and contaminated) of the Paranaguá Estuarine Complex (Paranaguá Bay and Laranjeiras Bay), Brazil. Aliphatic hydrocarbons were determined by the GC-FID to assess the status of contamination of the studied areas. The total DNA was extracted from these samples. The 16S rRNA gene was amplified by the PCR reactions with the pair of primers $21 \mathrm{~F}$ and $958 R$ for the archaeal domain, and $27 \mathrm{~F}$ and $1492 R$ for the bacterial domain. Comparisons of communities were made by the ARDRA technique, using the HinfI restriction enzyme. The phosphate concentration showed significant differences between the two regions. The aliphatic hydrocarbons analysis showed the presence of unresolved complex mixture (UCM), an indicator of oil contamination, in the samples from the Paranaguá Bay, which was corroborated by the concentration of total aliphatic hydrocarbons. The ARDRA profile indicated that the structure of archaeal and bacterial communities of the sampled areas was very similar. Therefore, the anthropogenic influences in the Paranaguá Bay showed to be not sufficient to produce disturbances in the prokaryotic dominant groups.
\end{abstract}

Key words: diversity, mangroves, Archaea, Bacteria, 16S rRNA, ARDRA, aliphatic hydrocarbons

\section{INTRODUCTION}

Mangrove ecosystems are home to a great diversity of species, and are responsible for the protection and stabilization of coastlines, conservation of the water quality, and support to coastal fisheries. (Kathiresan and Bingham 2001;
Krug et al. 2007; Froehner et al. 2012). The destruction of habitats by human activities has been the primary cause of loss of these ecosystems. In mangrove ecosystems, the pollution sometimes can't be visually detected. The sediments, for example, may contain a significant contamination by hydrocarbons even

*Author for correspondence: hedda@ufpr.br 
when there is no visual evidence of contamination in the trees or in the surrounding water (Kathiresan and Bingham 2001; Cury 2002). The microorganisms are essential to these ecosystems, especially in the control of their chemical environment. Soils and sediments appear to be one of the largest reservoirs of prokaryotic genetic diversity and are considered extremely complex environments (Robe et al. 2003).

Molecular techniques have emerged as a powerful tool to assess the impact of human activities on the prokaryotic diversity and ecological function of the mangrove ecosystem. According to Liang et al. (2007), although many studies conducted at the end of the 20th and early 21th century have collectively promoted a greater understanding of the phylogenetic composition of prokaryotic communities in the coastal sediments, investigations with this approach, carried out in mangrove ecosystems, are extremely scarce. This work represents the first description and assessment, by molecular techniques, of the human impact on the diversity of archaea and bacteria in mangroves sediments of the coastal areas of Paraná state, Brazil.

\section{MATERIAL AND METHODS}

\section{Studied area}

Brazil has one of the largest areas of mangroves in the world, ranging from the state of Amapá to the state of Santa Catarina (Krug et al. 2007). The Paranaguá Estuarine Complex (PEC) consists of two main water bodies: the Paranaguá and Antonina Bays on the southern (east-west) and Pinheiros, Laranjeiras and Guaraqueçaba Bays in the northern portion (north-south axis) (Fig. 1). The Laranjeiras Bay area is considered well preserved, with extensive areas of Atlantic forest and mangroves, and its main economic activities are fishing and seasonal tourism (Martins et al. 2012). The Paranaguá Bay, in turn, holds the two most active ports of the state, the Paranaguá and Antonina cities, as well as urban, tourist and industrial activities (Martins et al. 2010; 2011).

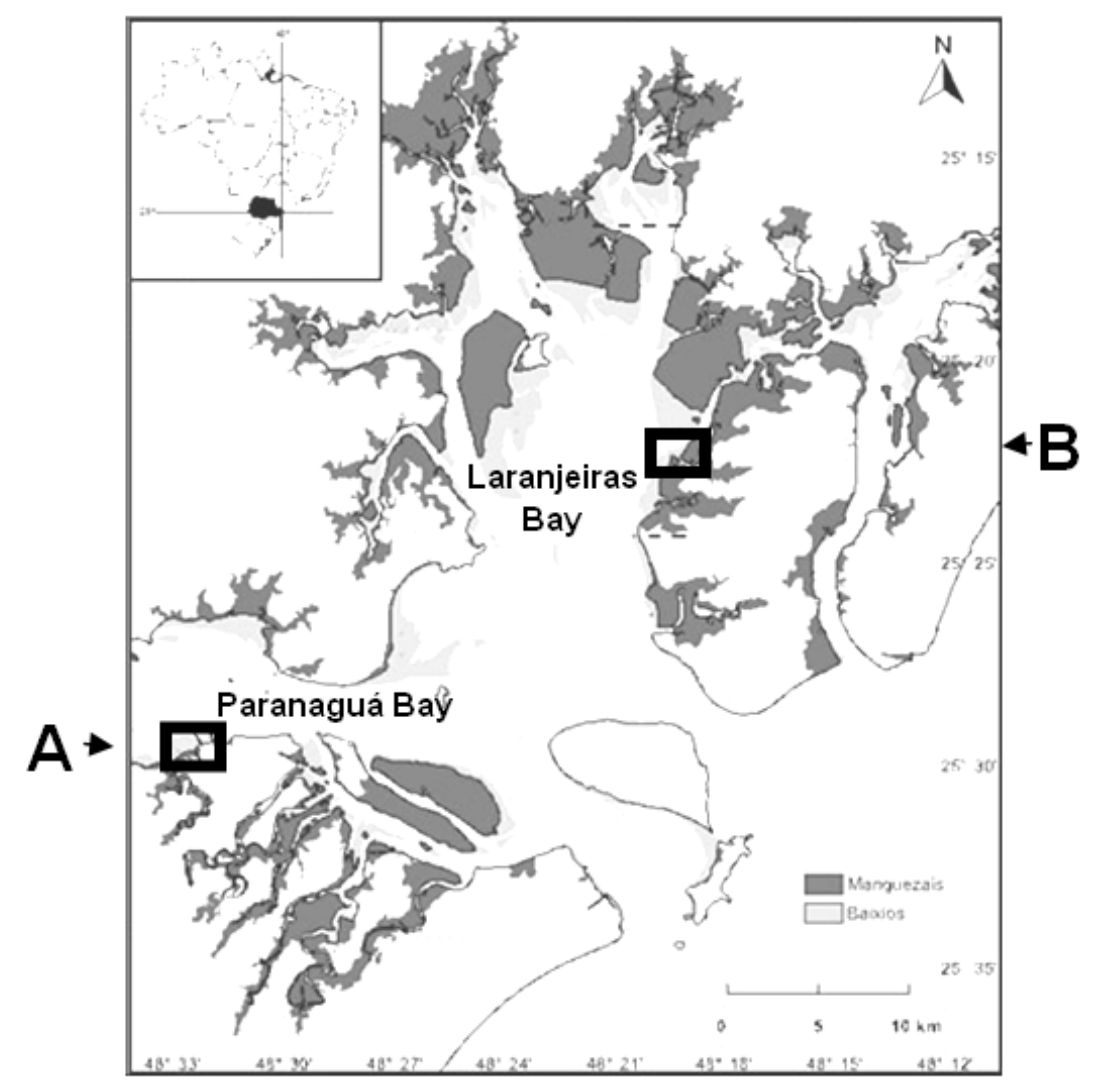

Figure 1 - Map of the Paranaguá Estuarine Complex with sampling points: Paranaguá Bay (A) and Laranjeiras Bay (B). 


\section{Samplings}

For the characterization of genetic polymorphism of mangroves, three surface mangrove sediment samples (up to $1 \mathrm{~cm}$ deep) were collected in each of the two regions (Paranaguá Bay $-25^{\circ} 22^{\prime} 41,1 " \mathrm{~S}$; $48^{\circ} 19^{\prime} 17,5^{\prime \prime} \mathrm{W}$ and Laranjeiras Bay $\left.25^{\circ} 22^{\prime} 40,9^{\prime \prime} \mathrm{S} ; 48^{\circ} 19^{\prime} 17,3^{\prime \prime} \mathrm{W}\right)$ of the Paranaguá Estuarine Complex. Samples were collected with sterile material, transferred to $50 \mathrm{~mL}$ Falcon-type tubes and placed on the ice for transport to the laboratory.

\section{Phosphate Quantification}

For the phosphate quantification, five samples were collected from each area. The samples were filtered through Schleicher \& Schuell GF filters $52 \mathrm{C}(\Phi=47 \mathrm{~mm})$. The analysis of phosphate concentrations were performed using the colorimetric methods described by Grasshoff et al. (1999) using a spectrophotometer (UV-1601, SHIMADZU), in the range of visible light. The total phosphorus was determined by the simultaneous oxidation with potassium persulfate and colorimetric measurement (Grasshoff et al. 1999).

\section{Aliphatic Hydrocarbons}

Two samples of each area were collected for the analysis of hydrocarbons. The upper layer $(2 \mathrm{~cm})$ was placed into pre-cleaned aluminum foil and then stored at $-15^{\circ} \mathrm{C}$. Then, the sediments were freeze-dried, homogenized in a mortar, sieved through a stainless steel mesh $(250 \mathrm{~lm})$ and stored in glass bottles until laboratory analysis. The analytical procedure adopted was that described by Martins et al. (2004). The aliphatic hydrocarbons analyses were performed with an Agilent GC (model 7890A) equipped with a flame ionisation detector and an Agilent 122-50-32 (DB5) capillary fused silica column coated with $5 \%$ diphenyl/dimethylsiloxane (length $=30 \mathrm{~m}$, ID $=$ $0.25 \mathrm{~mm}$, film thickness $=0.25 \mu \mathrm{m}$ ). Hydrogen was used as the carrier gas.

\section{Molecular Analyses}

Total DNA was extracted from the sampled sediment in less than $24 \mathrm{~h}$, using the UltraClean Soil DNA Kit ${ }^{\circledR}$ (MO BIO Laboratories, Inc). The product was used as template in the PCR with the $21 \mathrm{~F}$ and $958 \mathrm{R}$ pair of primers for $16 \mathrm{~S}$ rRNA for the archaeal domain, and $27 \mathrm{~F}$ and $1492 \mathrm{R}$ for the bacterial domain (Table 1). The cycles of amplification of the archaeal DNA were one cycle of $95^{\circ} \mathrm{C}$ for 5 minutes, followed by 30 cycles of $94^{\circ} \mathrm{C}$ for $1 \mathrm{~min}, 55^{\circ} \mathrm{C}$ for $1 \mathrm{~min}, 72^{\circ} \mathrm{C}$ for 1 minute and 30 seconds, followed by a final cycle at $72^{\circ} \mathrm{C}$, for 10 minutes. The cycles of amplification of DNA from the bacteria were: one cycle of $94^{\circ} \mathrm{C}$ for 3 minutes followed by 26 cycles of $94^{\circ} \mathrm{C}$ for 45 seconds, $55^{\circ} \mathrm{C}$ for 45 seconds, $72^{\circ} \mathrm{C}$ for 1 minute and 30 seconds, followed by a final cycle at $72^{\circ}$, for 10 minutes. Comparisons of communities of different sites were made by ARDRA (Amplified Ribosomal DNA Restriction Analysis), using the Hinfl restriction enzyme.

The product of digestion with HinfI was separated by the polyacrylamide gel electrophoresis. The resulting banding patterns were analyzed using the Labworks ${ }^{\circledR}$ program. This analysis is representative of the genetic polymorphism present in the samples. Therefore, each band do not represent a single species, but multiple microorganisms that have the same pattern of cutting sites for the enzyme, thereby releasing fragments with similar sizes.

Table 1 - Primers used for the amplification of the16S rRNA.

\begin{tabular}{|c|c|c|c|c|}
\hline Organism & Gene & Primer & Sequence & References \\
\hline \multirow{2}{*}{ Bacteria } & $16 \mathrm{~S}$ & $27 \mathrm{~F}$ & 5' AGAGTTTGATCMTGGCTCAG & \multirow{2}{*}{ Suzuki and Giovannoni (1996) } \\
\hline & rRNA & 1492R & 5' GGTTACCTTGTTACGACTT & \\
\hline \multirow[t]{2}{*}{ Archaea } & $16 \mathrm{~S}$ & $21 \mathrm{~F}$ & 5' TTCYGGTTGATCCYGCCRGA & \multirow[t]{2}{*}{ Moyer et al. (1998) } \\
\hline & rRNA & 958R & 5' YCCGGCGTTGANTCCAATT & \\
\hline
\end{tabular}

\section{RESULTS AND DISCUSSION}

\section{Phosphate}

The percentage of phosphate in the sediment was significantly higher in Paranaguá Bay (Fig. 2), where it was a minimum of $0.47 \%$ and maximum of $0.79 \%$. In the Laranjeiras Bay, the percentage of phosphate in the sediment fluctuated between $0.11 \%$ and $0.18 \%$. There were significant differences between the percentages of phosphate 
in the two areas, showing the human influence on the sampling stations of the Paranaguá Bay. Due to the fact that phosphorus has no atmospheric stable phases, such as nitrogen and carbon, the spread of this nutrient is accomplished primarily through the waterways (Filippelli 2008). The sampling area chosen was located between the FOSPAR (Phosphate Fertilizers of Paraná S/A) pier, where there was phosphorus discharge for fertilizer production, and the Anhaia Chanel, where there was discharge of the sewage of the city of Paranaguá.

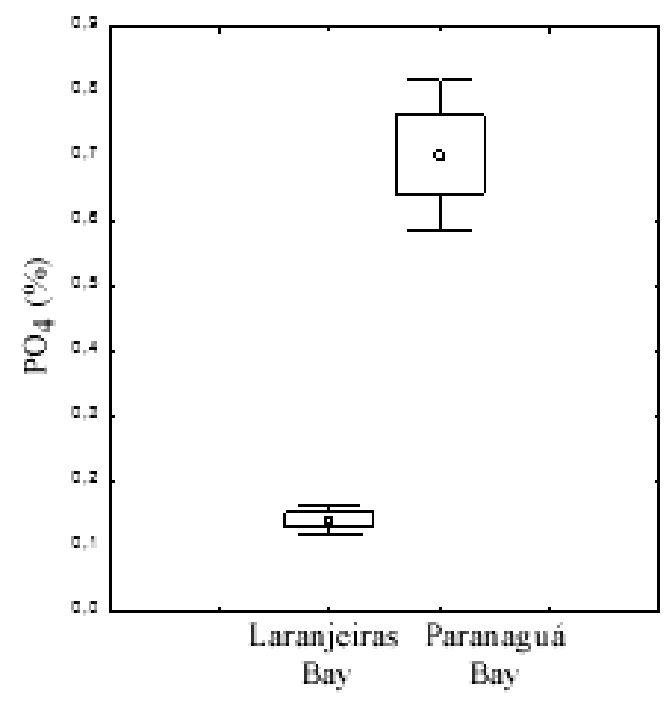

Figure 2 - Significant difference observed $(p=0.000015)$ for the percentage of phosphate between the stations of the bays of Paranaguá and Laranjeiras by the T-test analysis.

\section{Aliphatic Hydrocarbons}

The aliphatic hydrocarbons analysis showed the presence of unresolved complex mixture (UCM) in the samples from the Paranaguá Bay, with a maximum of $46.89 \mu \mathrm{g} . \mathrm{g}^{-1}$ (Fig. 3 and Table 2). The same was not observed in the samples from the Laranjeiras Bay. The presence of UCM could represent crude oil residues weathered or degraded by microorganisms, and it was an indicative of the contamination of the marine sediments by the hydrocarbons (Readman et al. 2002). The indicative of oil contamination in the stations of the Paranaguá Bay was corroborated by the relative high concentration of total aliphatic hydrocarbons ( $\Sigma$-AHs) and UCM/R ratio (> 5.0). Differences were observed between the $\Sigma$-AHs concentrations found in the two bays, thus indicating a possible contamination of the region close to the Paranaguá port. The sediment samples from the Paranaguá Bay showed higher concentrations of Total Alkanes, Resolved Aliphatic and total aliphatic in relation to the Laranjeiras Bay (Table 2), which was clear evidence that the two studied areas were under different environmental conditions.

Table 2 - Aliphatic hydrocarbons concentrations (in $\mu \mathrm{g} \cdot \mathrm{g}^{-1}$ ) and ratio of environmental analysis; *nd: not detected; nc: not calculated; L1 and L2: Samples from the Laranjeiras Bay; P1 and P2: Samples from the Paranaguá Bay.

\begin{tabular}{lcccc}
\hline & \multicolumn{3}{c}{ Samples } \\
\cline { 2 - 5 } Hydrocarbons $\left(\mu \mathrm{g}_{\mathrm{g}} \mathrm{g}^{-1}\right)$ & L1 & L2 & P1 & P2 \\
\hline Total Alkanes $\left(\mathrm{nC}_{10}-\mathrm{nC}_{40}\right)$ & 1.21 & 0.51 & 8.42 & 4.64 \\
Resolved Aliphatic & 1.51 & 0.76 & 8.70 & 4.92 \\
Unresolved Aliphatic $(\mathrm{UCM})$ & $\mathrm{nd}$ & $\mathrm{nd}$ & 46.9 & 46.5 \\
Total Aliphatic & 1.51 & 0.76 & 55.6 & 51.5 \\
Ratio & & & & \\
UCM/Resolved Aliphatics $(\mathrm{UCM} / \mathrm{R})$ & $\mathrm{nc}$ & $\mathrm{nc}$ & 5.39 & 9.46 \\
\hline
\end{tabular}




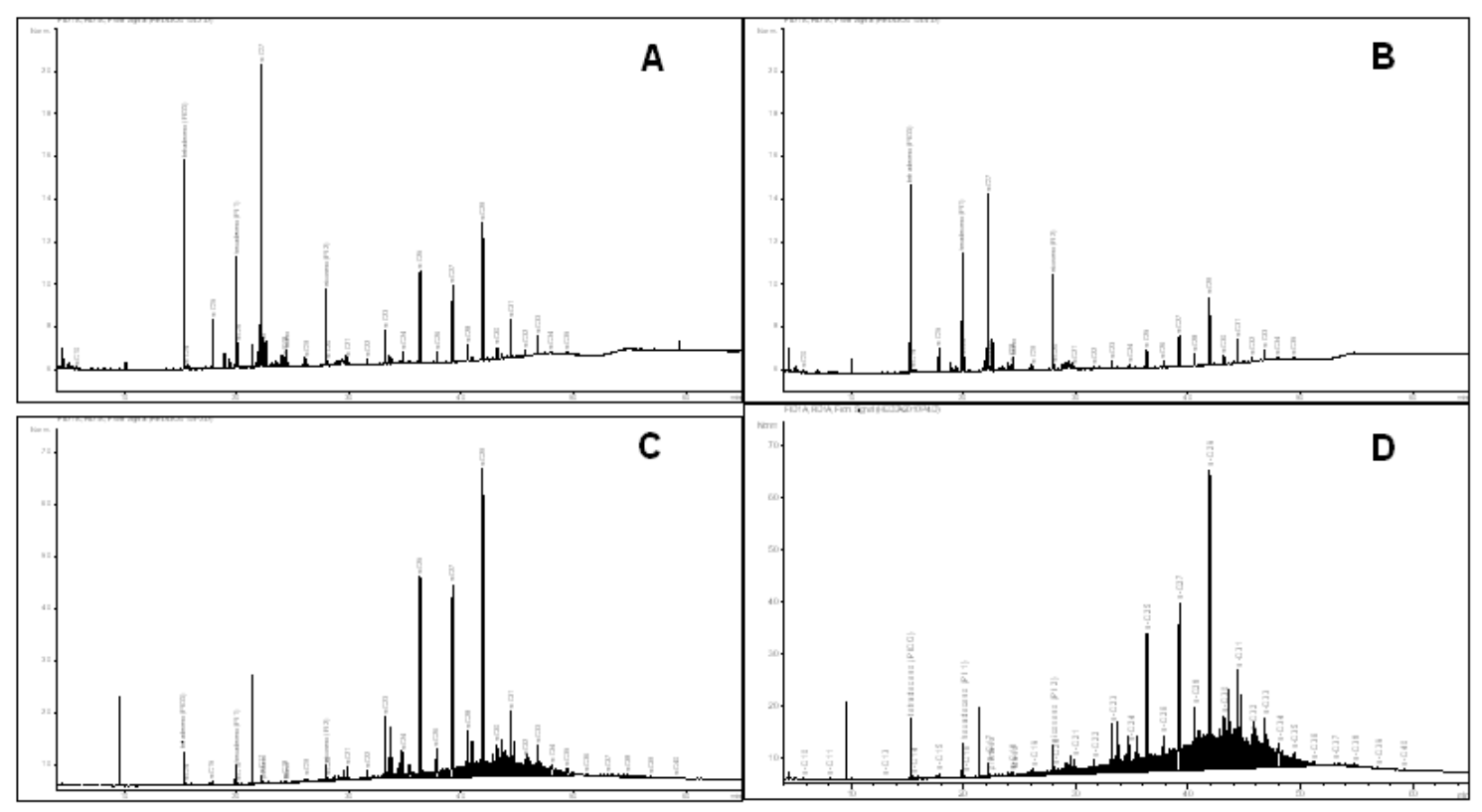

Figure 3 - Chromatograms of aliphatic hydrocarbons fraction of the two samples collected in the Laranjeiras Bay (A and B) and Paranaguá Bay (C and D). The presence of unresolved hydrocarbons, represented by the "hump" in C and D, is a clear indicative of oil contamination (Bouloubassi and Saliot 1993).

\section{ARDRA}

The ARDRA profile indicated that the structure of the prokaryotic communities was very similar, since there were no significant differences in the band's pattern within each area or between them. Richness, modified richness, diversity indices or dendrogram of similarity were not calculated due to the obvious similarity between the restrictions profiles obtained (Fig. 4).

Possibly, the weak influence over the structure of the archaeal and bacterial communities within each area was related to the fact that mangrove sediments were permanently saturated with water and homogenized by the tidal movement. Zhou et al. (2002) also showed that at the surface level, there is a reduced possibility to form micro-niches containing microbial communities with different structures. The maintenance of the archaeal community structure between the two areas could be related to this group's easy adaptation to extreme environments, as observed by Cury (2002), thus being less sensitive to the environmental changes. Liu et al. (2009) showed that in the soils contaminated with hydrocarbons, the community of archaea and bacteria might be even more complex than the communities of the
\end{abstract}

pristine environments. There were limitations of the used technique which detected only fluctuations in the communities' dominant groups. Despite that, it could be suggested that the observed anthropogenic influences in the Paranaguá Bay were not sufficient to generate the disturbances in the bacterial and archaeal community to the point of being observed by the ARDRA. For a complete characterization of microbial communities' differences, new sequencing technologies such as pyrosequencing of $16 \mathrm{~S}$ rRNA should be applied. Seeliger and Kjerfve (2001), reported that the Paranaguá Estuarine Complex was one of the least impacted coastal systems of Brazil. According to Marone et al. (2005), in highly dynamic systems such as estuarine systems, where there is a combination of continental and oceanic influences, as well the presence of seasonal cycles, differentiate between the changes caused by the natural changes or by the anthropogenic influence could be particularly difficult. It is difficult to form reliable estimates of how the prokaryotic diversity, both present in the mangroves as well as in any other ecosystem, changed over the decades due to human pressure. 


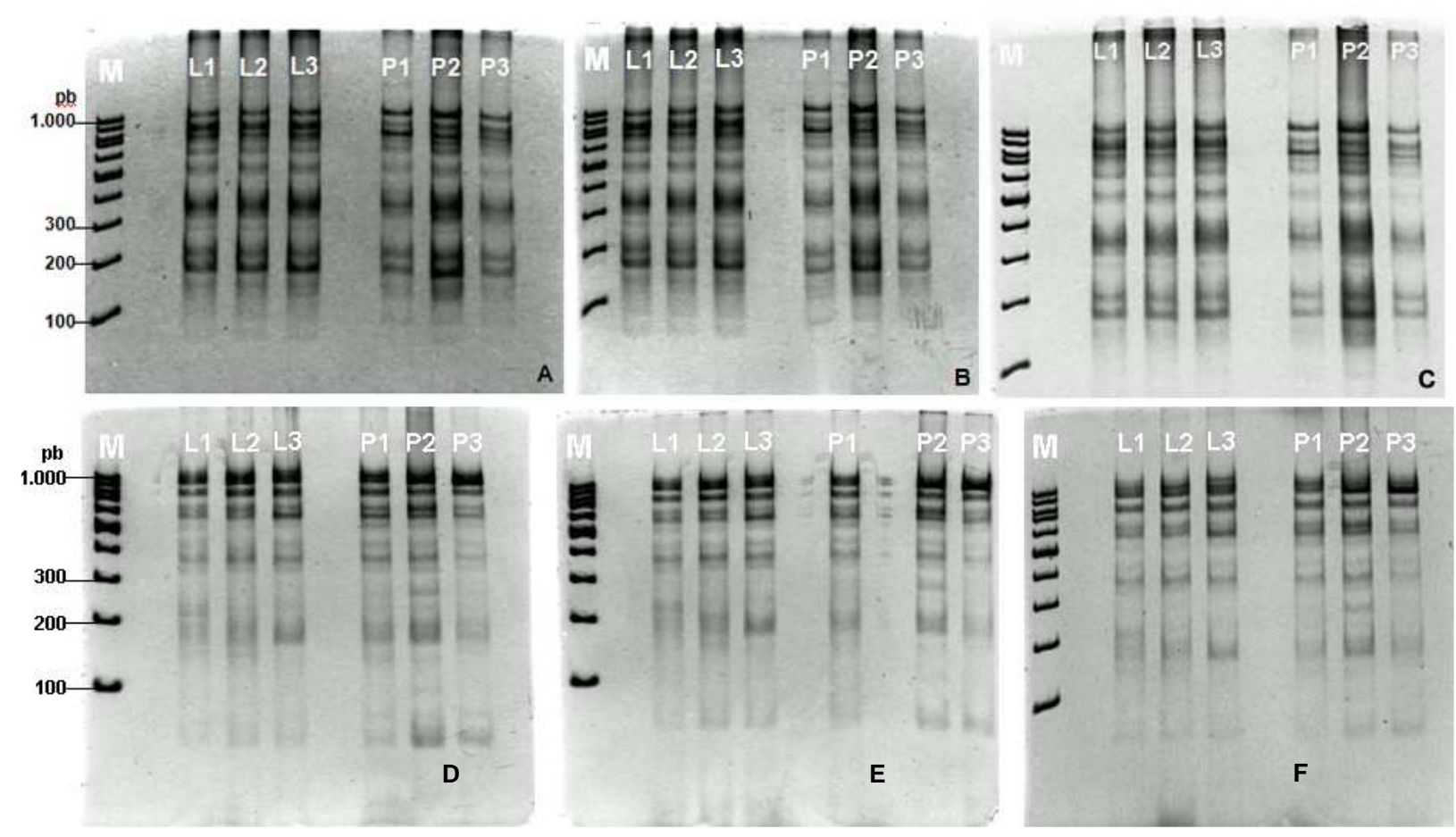

Figure 4 - ARDRA profiles of three replicates of three independent experiments in $12 \%$ nondenaturing polyacrylamide gel electrophoresis in 1x TAE running buffer, $100 \mathrm{~V}$, for 2 hours. Archaea (A-C) and Bacteria (D-F) 16S rDNA from the Laranjeiras Bay samples (L1-L3, 300ng) and Paranaguá Bay samples (P1-P3, 300ng) cleaved with HinfI. M: molecular size marker 100bp DNA ladder (500ng) Invitrogen ${ }^{\circledR}$.

The lack of information relies on the fact that the previous studies on these communities have long been dependent on cultivation, thus missing the major portion of their diversity. It would be interesting to conduct an extensive study of the response of prokaryotic organisms to human disturbance, using the molecular techniques with higher resolution in the mangroves and in other ecosystems.

\section{ACKNOWLEDGEMENTS}

We thank Professor Fabio de Oliveira Pedrosa, coordinator of the Center for Biological Nitrogen Fixation (UFPR), and the Millennium Institute / $\mathrm{CNPq}$ as financial contributors, as well as Professor Ricardo Ayub by yielding space, equipment and material for the development of molecular biology analyses. C.C. Martins was responsible to the hydrocarbons analyses. He thanks $\mathrm{CNPq}$ for a research grant $(564316 / 2008$ $3)$.

\section{REFERENCES}

Bouloubassi I, Saliot A. Investigation of anthropogenic and natural organic inputs in estuarine sediments using hydrocarbon markers (NAH, LAB, PAH). Oceanol. Acta. 1993; 16: 145-161.

Cury JC. Atividade microbiana e diversidades metabólica e genética em solo de mangue contaminado por petróleo. [Dissertação de Mestrado em Agronomia]. São Paulo: Universidade de São Paulo, 2002.

Filippelli GM. The global phosphorus cycle: Past, present, and future. Elements. 2008; 4: 89-95.

Froehner S, Machado KS, Stefan E, Bleninger T, Rosa EC, Martins CC. Occurrence of selected estrogens in mangrove sediments. Mar. Pollut. Bull. 2012; 64: 7579.

Grasshoff K, Ehrhardt M, Kremling K. Methods of Seawater Analysis. $2^{\text {nd }}$ ed. Weinheim: Verlag Chemie; 1999. 
Kathiresan K, Bingham BL. Biology of Mangroves and Mangrove Ecosystems. Adv. Mar. Biol. 2001; 40: 81251.

Krug LA, Leão C, Amaral S. Dinâmica espaçotemporal de manguezais no Complexo Estuarino de Paranaguá e relação entre decréscimo de áreas de manguezal e dados sócio-econômicos da região urbana do município de Paranaguá - Paraná. Anais XIII Simpósio Brasileiro de Sensoriamento Remoto, Florianópolis, Brasil. INPE, 2007: 2753-2760.

Liang JB, Chen YQ, Lan CY, Tam NFY, Zan QJ, Huang LN. Recovery of novel bacterial diversity from mangrove sediment. Mar. Biol. 2007; 150: 739747.

Liu R, Zhang Y, Ding R, Li D, Gao Y, Yang M. Comparison of archaeal and bacterial community structures in heavily oil-contaminated and pristine soils. J. Biosci. Bioeng. 2009; 108, 5: 400-407.

Marone E, Machado EC, Lopes R. M, Silva ET. Landocean fluxes in the Paranaguá Bay estuarine system, southern Brazil. Braz J Oceanogr. 2005; 53: 3-4.

Martins CC, Bícego MC, Taniguchi S, Montone RC. Aliphatic and polycyclic aromatic hydrocarbons in surface sediments in Admiralty Bay, King George Island, Antarctica. Antarct Sci. 2004; 16: 117-122.

Martins CC, Bícego MC, Figueira RCL, Angelli J FL, Combi T, Gallice WC, Mansur AV, Rocha ML, Wisnieski E, Ceschim LMM, Ribeiro AP. Multimolecular markers and metals as tracers of organic matter inputs and contamination status from an Environmental Protection Area in the SW Atlantic (Laranjeiras Bay, Brazil). Sci Total Environ. 2012; 417-418: 158-168.
Martins CC, Braun, JAF, Seyffert BH, Machado EC, Fillmann G. Anthropogenic organic matter inputs indicated by sedimentary fecal steroids in a large South American tropical estuary (Paranaguá estuarine system, Brazil). Mar. Pollut. Bull. 2010 ; 60: 21372143.

Martins CC, Seyffert BH, Braun JAF, Fillmann G. Input of Organic Matter in a Large South American Tropical Estuary (Paranaguá EstuarineSystem, Brazil) Indicated by Sedimentary Sterols and Multivariate Statistical Approach. In: J Brazil Chem Soc. 2011; 22: 1585-1594.

Moyer CL, Tiedje JM, Dobbs FC, Karl DM. Diversity of deep-sea hydrothermal vent Archaea from Loihi Seamount, Hawaii. Deep-Sea Res Pt II, 1998; 45, 303-317.

Robe P, Nalin R, Capellano C, Vogel TM, Simonet P. Extraction of DNA from soil. Eur J Soil Biol. 2003; 39: 183-190.

Seeliger U, Kjerfve B. Coastal Marine Ecosystems of Latin America. Berlin: Springer-Verlag; 2001.

Suzuki MT, Giovannoni SJ. Bias caused by template annealing in the amplification of mixtures of $16 \mathrm{~S}$ rRNA genes by PCR. Appl. Environ. Microbiol. 1996; 62: 625-630.

Zhou J, Xia B, Treves DS, Wu LY, Marsh TL, O'neill RV, Palumbo AV, Tiedje JM. Spatial and Resource Factors Influencing High Microbial Diversity in Soil. Appl. Environ. Microbiol. 2002; 68, 1: 326-334. 
PAGINA EM BRANCO 